\title{
KSIĘGOZBIORY I KSIĄŻKI RĘKOPIŚMIENNE W PRAWODAWSTWIE OGÓLNYM ZAKONU BRACI MNIEJSZYCH W PÓŹNYM ŚREDNIOWIECZU ${ }^{1}$
}

Najwcześniejsze prawodawstwo franciszkańskie w postaci obu reguł św. Franciszka z Asyżu z 1221 i 1223 r. nie zawierało przepisów o bibliotekach, czy choćby o jakimkolwiek korzystaniu z książek przez zakonników, dla których od początku istnienia zakonu musiały stanowić znacząca pomoc $w$ ich działalności. Pewien punkt wyjścia dla prawodawstwa studyjno-bibliotecznego stanowiło zezwolenie zawarte w pierwszej regule (1221) na posiadanie koniecznych narzędzi pracy ${ }^{2}$, właściwych dla tych zawodów, które zakonnicy

${ }^{1}$ Przez „Ordo Fratrum Minorum” (OFM) należy rozumieć założony przez św. Franciszka z Asyżu w 1209 roku „Zakon Braci Mniejszych”, który zatwierdził papież Honoriusz III w 1223 r. Istniał nie podzielony przez 300 lat, ale w jego łonie już od lat 30-tych XIII w. dawały o sobie znać tendencje odchodzenia od Reguty założyciela, a następnie powrotów do jej ściślejszego zachowania. Po okresie franciszkanów tzw. spirytualnych na przełomie XIII i XIV w., stojących na granicy błędnowierstwa i zwalczających wyjaśnienia papieskie do $R e-$ guty, jako zewnętrzne ingerencje - doszło w 2. poł. XIV w. do utworzenia nurtu reformistycznego, nawiązującego do wyjaśnień Reguły wydanych przez pap. Mikołaja III i Klemensa V i poddanego zupełnie autorytetowi Stolicy Apostolskiej, tzw. nurtu obserwantów. Wszystkie te wewnętrzne prądy dały podstawę do wydania przez papieża Leona X bulli „Idźcie i wy do winnicy" („Ite et vos in vineam”) w 1517 r., tworzącej dwa odrebne zakony: Braci Mniejszych (OFM) i Braci Mniejszych Konwentualnych (OFM Conv.). W wieku XVI z pierwszego z tych zakonów wyodrębnił się kolejny Zakon Braci Mniejszych Kapucynów. Pierwszy $\mathrm{z}$ wymienionych zakonów był popularnie nazywany regularną obserwancja, a w Polsce: prowincją bernardynów i prowincją reformatów.

Pod koniec XIX w. wielki papież Leon XIII wydał bullę „Felicitate quadam” (1897), w której połączył wszelkie odrębności w Zakonie Braci Mniejszych, zwanych dotąd obserwantami i franciszkanami i zabronił używania nazw partykularnych, szczególnie takich jak: obserwanci, alkantarzyści i dyskalceaci (bosi). Pozostałe do dziś nazwy: „bernardyni” i „franciszkanie reformaci" są nadal w użyciu w Polsce na zasadzie 500-letniej tradycji historycznej i literackiej. - Por. W. F. Murawi e c, Zarys dziejów Prowincji Niepokalanego Poczęcia NMP w Polsce. W: Schematyzm Prowincji oo. Bernardynów w Polsce i Kustodii na Ukrainie. Kraków 1997 s. 31; H. E. W y c z aw ski, Krótka historia Zakonu Braci Mniejszych, W: Klasztory bernardyńskie w Polsce w jej granicach historycznych. Kalwaria Z. 1985, passim.

${ }^{2}$ Reguła św. Franciszka z Asyżu z 1221 r. W: Pisma św. Franciszka z Asyżu. Przeł. K. A m brożk i ew i cz OFM Cap. Warszawa 1976, s. 55. 
wykonywali, zgodnie $z$ innym nakazem, by własną pracą zarabiali na utrzymanie. I faktycznie od samego początku zakonu bracia zajmujący się studiami, względnie kaznodziejstwem traktowali książki jako konieczne narzędzie pracy. Pierwszy profesor spośród braci mniejszych w Oksfordzie, Adam de Marisco ${ }^{3}$ wstapił do zakonu w latach 30-tych XIII w., wnosząc bibliotekę (księgozbiór), którą otrzymał w spadku po swoim stryju, biskupie Durham w Anglii, Ryszardzie de Marisco (1226) ${ }^{4}$. Zaczęły również powstawać biblioteki przy innych konwentach braci mniejszych położonych w miastach uniwersyteckich, w Cambridge ${ }^{5}$ i w Paryżu ${ }^{6}$, a jeszcze wcześniej w konwentach włoskich, jak np. w Arezzo, gdzie bracia otrzymali w 1232 r. teren pod budowę oraz wyposażenie $\mathrm{w}$ przedmioty codziennego użytku, a w tym także niewielki księgozbiór. Ofiarodawcą był zamożny mieszczanin tego miasta, niejaki Stefano znany tylko z imienia, który wycofał swoje jałmużny, gdy się okazało, że bracia zrezygnowali z budowy klasztoru w tym właśnie miejscu, które on podarowat. W zwiazku z tą sprawą znana jest interwencja samego papieża Grzegorza IX za pośrednictwem miejscowego biskupa, by niedoszły

3 Adam de Marisco (Marsh), angielski teolog, profesor w Oksfordzie, urodził się w drugiej połowie XII w. (zm. 18 listopada 1258). Studiował na wydziale Sztuk Wyzwolonych pod kierunkiem Roberta Grossetesta, angielskiego scholastyka, biskupa i profesora oraz przyjaciela braci mniejszych (franciszkanów). M. uzyskał mistrzostwo w $1226 \mathrm{r}$. i wstapił do franciszkanów w Worcester w 1232/1233 r. Powrócił do Oksfordu, by studiować teologię pod kierunkiem R. Grossetesta, który w 1235 r. został biskupem w Lincoln. W tym czasie M. wprowadził do studium uniwersytetu w Oksfordzie grupę franciszkanów, a wśród nich Rogera Bacona. Wszyscy oni pod jego kierunkiem uzyskali magisteria i zostali lektorami studium generalnego. Jako zaprzyjaźniony doradca biskupa Grossetesta M. udał się z nim na Sobór w Lyonie (1244-1246). Ok. 1247 r. został pierwszym franciszkańskim magistrem teologii w Oksfordzie, gdzie na Wydziale Teologicznym uczył do 1250 r. i był regensem studium gen. M-a wzywał król Henryk III do niektórych misji wagi państwowej. Z kolej arcybiskup Canterbury, Bonifacy z Savoy zwracał się do niego o radę. Zarówno król, jak i arcybiskup usiłowali bezskutecznie w 1256 r. mianować M-a biskupem w Ely. W 1257 r. M. należał do komisji badającej warunki wprowadzenia pokoju z Francja. W swoim życiu naukowym miał przydomek „,doktor prześwietny" (doctor illustris). R. Bacon uczeń M-a i Grossetesta wypowiedział się o swoich profesorach jako "największych duchownych na świecie" (the greatest clerics in tho world). - J. A. W e i s h e i p t, Adam Marsh, english theologian. W: New Catholic Encyclopedy. (NCE). T. 1. New York-San Francisco-London 1967, s. 117; Tenże, Robert Grosseteste. W: NCE, t. 12, s. 531; D. A. C a 11 u s, Robert Grosseteste. Oxford 1955, s. 41; L. Ott, Adam v. Marsh. W: LfThK. T. 1. Freiburg im B. 1957, kol. 132; A. G. L it l le, The Gray Friars in Oxford. Oxford 1892, s. 134 n.; Tenże, The Franciscan School at Oxford in the 13. century. "Archivum Franciscanum Historicum" („AFH") 19:1926, s. 831 n.; G. C a n t in i, Adam de Marisco. "Antonianum" 23:1948, s. $441 \mathrm{n}$.

${ }^{4} \mathrm{~A}$. G. Little, The franciscan school at Oxford in the thirteenth century. „AFH". R. 19:1926 s. $831 \mathrm{n}$.

${ }_{5}$ W latach 1250-1252 w konwencie braci mniejszych w Cambridge funkcjonowalo studium generalne jako szkoła uniwersytecka. Nie ulega wątpliwości, że studium to miało swój ksieggozbiór. - V. D o u c e t OFM, Le studium franciscain de Norwich en 1337. "AFH" R. 46:1953, s. 86 .

${ }^{6}$ Autor konstytucji narbońskich z 1260 r. opracował również w oparciu o poprzednie prawodawstwo - Regulamin (Ordinationes) Studium Gen. i Biblioteki Konwentu OFM w Paryżu. - S. B o n a w en tura, Opera omnia. t. 8. Ed. Collegii s. Bonaventurae. Quaracchi (Grota Ferrata) 1898, s. $457 \mathrm{nr} 6$. 
fundator, Stefano z Arezzo zwrócił braciom ksiażki i inne przedmioty, które im wcześniej ofiarowal?

Najwcześniejsze konstytucje zakonu tzw. prenarbońskie, sprzed 1260 r., których dokładna data wydania nie jest znana, zawierały już pewne wskazania o księgozbiorach klasztornych i używaniu książek przez braci. Powtarzały je później następne zbiory prawodawstwa zakonnego, do XV wieku włącznie. Najwięcej równoległych powtórzeń znalazło się $\mathrm{w}$ bezpośrednio nastepnych konstytucjach tzw. narbońskich, wydanych w $1260 \mathrm{r}^{8}$ Były to przepisy prawne podkreślające wyjątkowość książek wśród wszystkich innych dóbr materialnych, oraz innych przedmiotów kosztownych. Wspomniane konstytucje przewidywały ich przepisywanie jedynie na własny użytek, natomiast zakazywały ich tworzenia w skryptoriach zakonnych w celu sprzedaży lub zamiany ${ }^{9}$. Zakonnicy nie zajmujacy się studiowaniem nie mogli posiadać nawet czasowo, Pisma św. Starego czy też Nowego Testamentu, które wówczas należały do ksiąg stosunkowo najbardziej kosztownych ${ }^{10}$. Również innych kodeksów nie mogli posiadać bez zezwolenia ministra prowincjalnego (prowincjała) ${ }^{11}$. Takie zezwolenie uzyskiwali jedynie zakonnicy uznani przez przełożonych za odpowiednich do studiowania oraz lektorzy zakonni i kaznodzieje $^{12}$. Uprzywilejowane było szczególnie studium paryskie, na które wysyłano po dwóch studentów z poszczególnych prowincji zakonnych, i choć początkowo nie przewidywano dla nich osobnej prowizji - mieli bowiem zapewnione utrzymanie w tamtejszym konwencie - uczyniono jednak $\mathrm{z}$ czasem wyjątek ze względu na konieczność nabywania książek. Prowincjał wraz z kapituła prowincjalną miał im zapewnić według swojego uznania, opłaty potrzebne dla lektorów oraz na zakup książek, a także na bieżące skrypty ${ }^{13}$.

Autorzy obu wspomnianych konstytucji, a więc ówczesny minister generalny zakonu, św. Bonawentura oraz jego poprzednicy na urzędzie wyrażali troskę o całość powstających około połowy XIII w. księgozbiorów klasztornych, w związku z czym z tego właśnie czasu pochodzi nakaz zwrotu książek do prowincji macierzystej, po śmierci zmarłego brata studiującego, względnie tego, który przeniósł się do innej prowincji zakonu wraz z użytkowanymi przez siebie ksiazżkami. Był to ważny problem dnia codziennego, gdyż wybitniejsi kaznodzieje, lektorzy studiów generalnych i uniwersyteccy pracowali często poza swoją prowincją zakonna, i szczególnie ci ostatni posiadali niekiedy znaczne księgozbiory, powiększane nakładem finansowym macie-

${ }^{7}$ Papież Grzegorz IX, Ad audientiam nostram (1232). W: Bullarii Franciscani Epitome. Pod red. C. E u b la. Quaracchi 1908, s. 10 nr 91.

${ }^{8}$ Porównania tekstów obu konstytucji, prenarbońskich i narbońskich dokonał Cesare Cenci w artykule pt. De Fratrum Minorum Constitutionibus Praenarbonensibus. "AFH". R. 83:1990, fasc. 1.2, s. 50-95.

${ }_{9}^{9}$ C. C e n c i, De Fratrum Minorum Constitutionibes Praenarbonensibus, s. 92 nr 78.

${ }^{10}$ Studenci nauk bibl. mieli zakaz kupowania kosztowniejszych wydań Biblii, których cena za egzemplarz wykraczała ponad „20 librarum Parisiensium”. - Tamże, s. 93 nr 84.

${ }^{11}$ Tamże, s. $93 \mathrm{nr} 80$.

12 Tamże.

${ }^{13}$ Tamże, s. 93 nr 82. 
rzystej prowincji. Dotyczyło to również studentów paryskiego Uniwersytetu oraz innych uniwersytetów. Przyjęto więc zasadę przynależności wydatków (jałmużny), za które te dzieła zostały nabyte ${ }^{14}$. O ile więc zostały kupione lub uzyskane w inny sposób, już z funduszów nowej prowincji, to mogły tam pozostać. W przeciwnym przypadku miały powrócić do prowincji macierzystej zmarłego. W związku z tym przepis konstytucji nakazywał braciom przenoszącym się do konwentu innej prowincji, sporządzić rejestr dzieł według autorów kodeksów (,nomina librorum”), które zabierał ze sobą, i miał go wręczyć prowincjałowi macierzystej prowincji ${ }^{15}$. Jest to pierwsza wzmianka w prawodawstwie zakonnym braci mniejszych, dotycząca konieczności sporządzania rejestru książek, a pod określeniem „nomina librorum” należy rozumieć nazwiska autorów i tytuły dzieł.

Prawodawstwo ogólnozakonne od początku miało mocne oparcie w dokumentach papieskich, szczególnie w bullach Grzegorza IX, Inocentego IV, Aleksandra IV, Klemensa IV i Mikołaja III. Wydawali oni bulle wyjaśniające Regułe św. Franciszka, dostosowując ją do wymogów i narastających potrzeb rozwijającego się Zakonu Braci Mniejszych. Dotyczyło to w dużej mierze studiów i bibliotek, na których rozwój należało znaleźć konieczne środki finansowe, pomimo zakazu używania pieniędzy, zawartego w Regule. Bulle papieskie wyjaśniały, nawiązując do Reguty, że tak jak potrzeby chorych, również potrzeby braci studiujących należy załatwiać przez przyjaciół duchownych. Przyjaciel św. Franciszka, kardynał Hugolino, który w rok po jego śmierci został papieżem pod imieniem Grzegorza IX (1227-1241), ogłosił bullę wyjaśniającą Regute św. Franciszka, a w szczególności problemy związane ze ślubem ubóstwa i zakazem używania pieniędzy. Rozpoczął ją od słów: "Quo elongati" ("Czym oddaleni «od świata»") ${ }^{16}$, wyjaśniając, co braci

${ }^{14}$ Tamże.

15 Constitutiones Generales Narbonenses (1260). W: S. B on a v n tura, Opera omnia. T. 8. Ed. Collegii s. Bonaventurae. Quaracchi (p. Florentiam) 1898, s. 457 nr 6.

${ }^{16}$ Grzegorz IX, Ugolino z Segni (1170-1241) był papieżem od 1227 r. Studiował teologię w Paryżu oraz prawo w Bolonii. W 1198 r. zostal kardynałem, a następnie biskupem Ostii (1206). W czasie swojego pontyfikatu gorliwie szerzył idę poparcia dla wypraw krzyżowych. W związku z tym ekskomunikował cesarza Fryderyka II w 1227 i w roku następnym za zaniechanie wzięcia udziału w krucjacie, pomimo wcześniejszego zobowiązania się ślubem. W 1228-1229 G. odzyskał część Królestwa Sycylii i Neapolu, które cesarz zajął po powrocie z Jerozolimy (1229). W 1230 r. doszło do zawarcia pokoju z cesarzem w San Germano, mocą którego papież zdjął z Fryderyka kary kościelne, a ten z kolei zwrócił zajęte terytoria Państwa Kościelnego. Po 9 latach cesarz ponownie zajął Sycylię, będącą lennem Stolicy Áp. i ponownie został ukarany ekskomunika ( $(1 \overline{2} \overline{3} \hat{y})$. Pođiczas wojny z papieżem, cesarz unıemożliwił obrady Soboru, zwołanego na 1241 r. i zajął dalsze terytoria kościelne. G. popierał braci mniejszych i dominikanów w ich działalności misyjnej na wschodzie Europy, oraz krzyżaków, którym zatwierdził w 1234 r. nadanie księcia Konrada mazowieckiego. Zwalczał błędnowierstwo, reorganizując inkwizycję. Jako kardynał był protektorem braci mniejszych (franciszkanów) od 1220 r. i troszczył się o wzmocnienie ich wewnętrznej organizacji, która wprowadzał po śmierci św. Franciszka $(\uparrow 1226)$ brat Eliasz z Kortony. G. wydał ważną dla franciszkanów bullę "Czym oddaleni” (Quo elongati) w 1230 r., wyjaśniając Regułę Franciszka i jego Testament. Podkreślał konieczność nabywania książek przez braci studiujących. 
św. Franciszka oddala od świata, a co przybliża. Korzystanie z ksiazżek i posiadanie ich zostało uznane przez autora bulli za przedmioty potrzebne w codziennym użytku (,utensilia et libri”) na równi z tymi ruchomościami, z których wolno korzystać (,eorum usum habeant...”), w takim jednak zakresie, jaki ustalą zakonni przełożeni - generał zakonu i prowincjał ${ }^{1}$.

Papieź Inocenty IV ${ }^{18}$ (1243-1254) w bulli „Ordinem vestrum” (,Wasz zakon") w 1245 r. uznał książki za ważne przedmioty codziennego użytku dla zakonników studiujących, wymieniając je na równi z budynkami mieszkalnymi braci oraz ruchomościami codziennego użytku, które wolno posiadać. Z tym tylko, że, jak to już wyjaśnił pap. Grzegorz IX, zakon nie ma do nich prawa własności, a tylko prawo użytkowania, a więc bracia nie mogą ich sprzedawać, ani wydawać na stałe poza zakon, chyba tylko za zgodą Stolicy Apostolskiej ${ }^{19}$.

Z kolei pap. Aleksander IV (1254-1261) ${ }^{20}$ zezwolił klasztorom braci mniejszych przyjmować zapisy w postaci książek, podobnie jak inne ko-

W tejże bulli dał przyzwolenie na przyjmowanie pieniędzy, za pośrednictwem osób spoza zakonu. Jego dziełem jest zbiór prawa kanonicznego pod nazwą „Dekretałów Grzegorza IX”. Zmarł w Rzymie 22 VIII 1241 r. - T. B a c h, Grzegorz IX. W: EK T. 6. Lublin 1993, kol. 338 n.; R. Mans elli, Federico II e Georgio IX. Appunti di una ricerca. „Studii Storici Meridionali" 2:1982, s. 5 n.; E. Pás ztor, San Francesco e il kardinale Ugolino nella "questione francescana". „CF" 46:1976 z. 3-4, s. 209 n.; O. B o n m a n n, Gregor IX. W: LfThK. T. 4. Freiburg im B. 1960 , s. 1186 n.

${ }^{17}$ Szczegółowe rozwiązania prawodawca zlecił w „Konstytucjach”, przełożonym zakonnym. - H. Holzap e l, Manuale historiae Ordinis Fratrum Minorum. Przel. G. H ase 1 beck. Friburg im Brisgau 1909, s. 21 n.; Grzegorz IX pap., Quo elongati (I230). W: L. Wad ding, Annales Minorum. T. 2. Quaracchi (p. Florentiam) 1931, s. 276 n. (246) nr 14.

${ }^{18}$ Innocenty IV, Sinibald Fieschi był papieżem w latach 1243-1254. Studiował prawo w Uniwersytecie Bolońskim. W 1227 r. został kardynałem. Jako papież był zamieszany w wojnie z Hohenstaufami. Zwołał Sobór lyoński I w 1245 r., na którym kontynuowano reformę Kościoła i uchwalono pomoc dla Ziemi Św., wcześniej bowiem Turcy zajęli Jerozolimę. Obradowano też nad sprawą cesarza Fryderyka II, którego wcześnie ekskomunikował Grzegorz IX. Inocenty reformował zakony mendykanckie, ożywił dialog z prawosławiem, rozbudował inkwizycję. Za jego pontyfikatu doszło do pewnych działań w kierunku reformy Kościoła w Polsce, szczególnie w kwestii obowiązku rezydencji przez beneficjantów, ograniczenia kumulacji beneficjów kościelnych. Kanonizował w Asyżu w 1253 r. Biskupa krakowskiego św. Stanisława, zezwolił na koronacje litewskiego Mendoga; erygował m.in. diecezje chełmińską i warmińska, popierał misje na Rusi, doprowadzając do koronacji, skłaniającego się ku Rzymowi, księcia Daniela Halickiego. Był od roku 1253 protektorem Polski. Zmarł w Rzymie w 1254 r. - K. Śmig i e 1, Innocenty IV. W: EK. T. 7. Lublin 1997, kol. 250; K. Pennington, Pope and Bishop. The papal Monarchy in the Twelfth and Thirteenth Centuries. Philadelphia 1984; H. Z i mme rma n n, Das Papstum im Mittelalter. Stuttgart 1981.

${ }^{19}$ In noc e n tiu s IV, Ordinem vestrum (I245). W: Bullarii Franciscani Epitome et Supplementum. Red. et ed. C. E u b e 1. Quaracchi 1908, s. $238 \mathrm{nr} 11$.

${ }^{20}$ Aleksander IV, Rinaldo z Segni (zm. 1261) był papieżem od 1254 r. Kreowany kardynałem w 1227 r. przez Grzegorza IX, którego był bratankiem. W polityce był zdecydowanym przeciwnikiem Hohenstaufów, natomiast zawarł przymierze z bizantyńskim Teodorem II Laskarysem. Za jego pontyfikatu doszło do zajęcia Sycylii przez uzurpatora Manfreda (1258). A. poszerzył dekrety wzmacniające inkwizycję, do walki z herezjami w północnych Wloszech 
niecznie potrzebne rzeczy, np. materiał na budowę kościołów, względnie przedmioty służące do jego oświetlenia i przyozdobienia ołtarzy. I nikt nie może im w tym przeszkadzać pod karą ekskomuniki. W przypadku translokacji mogą bracia zabrać książki do nowego miejsca zamieszkania, podobnie jak materiał budowlany kościoła oraz paramenty $\mathrm{i}$ argenteria kościelne ${ }^{21}$. Podobne przepisy o nabywaniu i zabezpieczaniu ksiazzek oraz całych księgozbiorów klasztornych, pomimo braku prawa własności ze strony zakonu, wydał kolejny papież Klemens IV (1265-1268), kładąc książki na równi z przedmiotami koniecznymi w szerzeniu kultu Boźego oraz w codziennym utrzymaniu konwentu ${ }^{22}$.

Słowa Ewangelii św. Mateusza o Siewcy ${ }^{23}$ dały natchnienie papieżowi Mikołajowi III (1277-1280 $)^{24}$ do napisania bulli wyjaśniającej wszystkie 12 rozdziałów Reguły św. Franciszka, zaczynając ją od pierwszych słów przypowieści Chrystusa: „Exiit, qui seminat” („Oto Siewca wyszedł siać...”).

i południowej Francji. Planował wyprawy krzyżowe szczególnie przeciw Tatarom, Jaćwingom i Litwinom. Bronił zakony mendykanckie, poteppiając pisma im wrogie (Wilhelma de SaintAmour oraz Gerarda z Borgo). Kanonizował św. Klarę z Asyża, przywrócił profesorów z zakonow mendykanckich na katedry uniw., utracone za opozycję przeciw duchowieństwu diecez. - M. P oll a k ó w n a, Aleksander IV. W: EK. T. 1. Lublin 1973, kol. 326; S. S i b i l i a, Aleksander IV (1254-1261). Anagni 1961; J. Helle r, Die Herkunft Papst Alexander IV. „Quellen u. Forschungen aus Italienischen Archiven u. Bibliotheken”. 32:1942, s. 254.

${ }^{21}$ Pap. Aleksander IV, Virtute conspicuos (1258). W: Bullarii Franciscani Epitome..., s. 266 n., nr 35.

${ }^{22}$ Pap. Klemens IV przejął bullę poprzednika „Virtute conspicuos”, w której Stolica Apostolska potwierdzała wszystkie dotychczasowe przywileje Zakonu Braci Mniejszych, a w tym również ustalenia dotyczące książek i bibliotek klasztornych. - Por. Bullarii Franciscani Epitome..., s. $288 \mathrm{nr} 43$.

${ }^{23}$ Mat 13, 13.

${ }^{24}$ Mikołaj III, Giovanni Gaetano Orsini (1210-1280) byl papieżem od 1277 r. Kardynałem kreowany w 1244 r. przez pap. Innocentego IV, był w Kurii pap. wpływową osobistością, szczególnie podczas konklawe papieży. Mianowany przez pap. Urbana IV rektorem u św. Sabiny i protektorem Zakonu Braci Mniejszych (franciszkanów). Pełnił ważne misje polityczne Stolicy Apostolskiej. Przeprowadził reformę papieskiej administracji, szczególnie sądownictwa. Unia z Grekami, zawarta na Soborze Lyońskim II w 1274 r. okazała się nieudana, gdyż cesarz wschodni nie był w stanie jej wyegzekwować u swoich poddanych, stąd Mikołaj III zwrócił się z żądaniem zastosowania mocniejszych środków dla jej wyegzekwowania. Unia była od początku traktowana jako pierwszy krok w organizowaniu wielkiej krucjaty w celu odzyskania Ziemi Św., a jej niepowodzenie udaremniło realizację tych planów. M. został zmuszony do zajęcia stanowiska w kontrowersyjnej kwestii franciszkańskiego ubóstwa, która podzieliła zakon na konwentualnych i spirytualnych. Rozstrzygnięcia papieża zostały zawarte w bulli „Wyszedł Siewca” („Exiit, qui seminat”), wydanej w 1279 r., która wraz

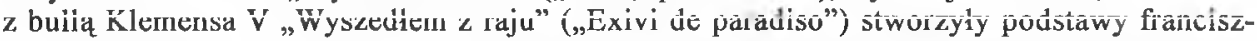
kańskiej obserwancji. Papież ten doprowadził do finału w sprawie konfliktu o przynależność polityczną Sycylii, między Andegawenami a Habsburgami (1280). M. utrwalił papieską rezydencje na Watykanie. Zmarł 22 sierpnia $1280 \mathrm{r}$. Został pochowany w kaplicy św. Mikołaja w Bazylice Św. Piotra. - J. M. Muld o o n, Nicholas III Pope. W: NCE. T. 10. New York-San Francisco-London 1967, s. 442-443; D.P. W a le y, The Papal State in the l3th Century. NY 1961; B. Rusch, Die Behörden u. Hofbeamten der päpstlich, Kurie des $13 \mathrm{Jh}$. Königsberg 1936; E. Du pré-These ider, Roma dal Comune die popolo alla Signoria pontificia. Bologna 1952; A. D e m e s k i, Papst Nicolaus III. Münster 1903. 
Fragment bulli poświęcony studiom i bibliotekom stanowi tu prawdziwą ich apologię, w oparciu o nakaz św. Franciszka w formie upomnienia (Regula, rozdz. 9), by słowa głoszone przez kaznodziejów, „były wypróbowane i czyste na pożytek i zbudowanie ludu" ${ }^{25}$. Na zasadzie prostego rozumowania logicznego Mikołaj III udowadnia, iż św. Franciszek wymagając od zakonników wysłowienia czystego i wypróbowanego w kazaniach, zakłada w Regule wiedzę kaznodziejska, która z kolei wymaga studiów. Studia z kolei można realizować tylko przy użyciu książek ${ }^{26}$. Wysuwa ponadto piękną analogię, porównując pisanie ksiagg i wspomaganie piszących - do budowy budynków mieszkalnych braci oraz kościołów („pro fabrica ecclesiae”), jak również potrzebnych materiałów budowlanych ${ }^{27}$.

Książki w późnym średniowieczu, zawierające traktaty teologiczne, prawne oraz poglądy znanych filozofów były w wielkiej cenie. Większe klasztory, szczególnie studyjne posiadały własne skryptoria, gdzie przepisywano księgi liturgiczne oraz kodeksy z różnych dziedzin wiedzy celem zaspokojenia wyłącznie wewnętrznego popytu. Wszelkiego rodzaju handel książami, jak wyżej wspomniano, był zabroniony pod sankcją kar kościelnych. W przypadkach wyjątkowych można było uzyskać zezwolenie wyższych przełożonych, na sprzedaż, by zaspokoić wyjątkowo ważne potrzeby konwentu. Takiego zezwolenia łatwiej udzielano w konwentach ze studiami generalnymi, a szczególnie przy uniwersytetach, gdzie było większe zapotrzebowanie na pozycje podręcznikowe i skrypty. Chodziło więc o większą oszczędność. Utarła się nawet praktyka, że droższe egzemplarze Biblii, będące w posiadaniu studentów, przełożony miał obowiązek im zabrać, a następnie spieniężyć, w celu kupienia kilku innych, tańszych egzemplarzy i rozdzielić wśród tych, którzy ich nie posiadali.

W historii zakonu św. Franciszka podobnie jak w dziejach Kościoła powszechnego wiek XIV przebiegał pod znakiem kryzysu wewnętrznego, upadku starych struktur i tworzenia się nowych. Najpierw doszło do ostatecznego rozprawienia się ze spirytualizmem (1317), graniczącym z herezją którego główne podłoże stanowiła nauka cystersa Joachima de Fiore (zm. 1202), a Reguła św. Franciszka była jedynie punktem wyjścia. Następnie w latach dwudziestych XIV w. doszło do konfrontacji z papieżem Janem XXII w kwestii ubóstwa i prawa własności dóbr użytkowanych przez zakon, które jego poprzednicy przenieśli na Stolicę Apostolską jako właściciela. Jan XXII po prostu zrzekł się tego prawa, pozostawiając zakon jakby w próżni i narażając klasztory na pewną dezorganizację w zachowaniu Reguty i tym samym przyczyniając się do opuszczania zakonu przez wielu jego członków, którzy

${ }^{25}$ Pisma św. Franciszka z Asyżu. Przeł. K. A mbrożki e wi c z. Warszawa 1982, s. 102 nr 9.

${ }^{26}$ „Ex quibus omnibus satis claret ex Regula (quod) ad dictum vestitum, divinum cultum et sapientialem studium necessariarum rerum usum esse concessum fratribus" - Por. pap. M i k oł a j III, Exiit, qui seminat (1279), W: Bullarii Franciscani Epitome..., s. 294 nr 47.

27 Tamże, s. $295 \mathrm{nr} 47$. 
przenosili się do innych zakonów, szczególnie mniszych ${ }^{28}$. Nie bez znaczenia była również wojna cesarstwa z papiestwem i uciążliwa kara interdyktu nałożona przez papieża na kraje sprzyjające cesarzowi. Stanowiła pretekst dla wielu zakonników, do opuszczania klasztorów w celu poszukiwania miast, w których jeszcze kara interdyktu nie obowiązywała i normalnie odprawiano $\mathrm{msze}^{29}$. Ponadto do wyludnienia konwentów przyczyniła się również epidemia tzw. „czarna śmierć”. Miary zamieszania i dezorganizacji dopełniła schizma zachodnia w 1378 r., która rozbiła zakon na dwie tzw. obediencje, podległe papieżowi i antypapieżowi, $\mathrm{z}$ dwoma, a następnie trzema generałami zakonu.

W drugiej połowie wieku XIV powstał nowy prąd odnowy życia klasztornego u braci mniejszych (franciszkanów), jako tzw. „regularna obserwancja", zapoczątkowana w niewielu początkowo klasztorach w Italii, przez Jana Valle (zm. 1351), następnie Gentilisa de Spoleto (zm. 1360), a najbardziej przez Pawła Vagnozzi da Trinci (zm. 1390) ${ }^{30}$. Ugrupowanie Pawła Vagnozz' iego wzrosło w siłę, gdy zaakceptowali je generałowie zakonu, a jego członkami i komisarzami generalnymi stali się w XV w. wybitni święci reformatorzy i kaznodzieje, jak Bernardyn ze Sieny (zm. 1444) ${ }^{31}$, Albert z Sarteano (zm. 1450), Jan Kapistran (zm. 1456) i Jakub z Marchii (zm. 1476).

Prawodawstwo zakonne w latach kryzysu, a więc kolejne konstytucje tzw. padewskie (1310), oraz farynierskie (1354), z wyjątkiem benedyktyńskich (1336) usiłowały rozwiązywać wspomniane wyżej problemy, a kwestie związane ze studiami i bibliotekami pozostawiały na poziomie ustaleń prawodawstwa $\mathrm{z}$ wieku XIII, a szczególnie konstytucji narbońskich (1260), stworzonych przez św. Bonawenturę. Pewną nowością była już w latach trzydziestych XIV w. ustawa o tworzeniu księgozbiorów i bibiiotek jako własności zakonu, jak to było w innych zakonach mendykanckich. Już bowiem nie podkreślano jak dawniej, że bracia są tylko ich przejściowymi użytkownikami. Stąd już konstytucje padewskie (1310), a potem następne do farynierskich włącznie (1354) wprowadziły nawet sankcję karną w postaci pozbawienia delikwentów osobistych księgozbiorów i aktów prawnych, za wykroczenia przeciw ślubom zakonnym, szczególnie czystości („suspecta consortia et colloquia cum mulieribus"). Była to kara zaliczana przez współczesnych za jedną z najcięższych kar, nakładana za niepoprawność mimo wcześniejszych upomnień. Wprawdzie prawodawca zamieścił klauzulę, że gdyby ta sankcja karna nie była aktualnie odpowiednia, to prowincjał mógł nałożyć inną równoważną sankcję, to jednak samo zagrożenie pozbawienia możliwości korzystania z książek, świadczyło o wyjątkowej uciążliwości kary, która

${ }^{28} \mathrm{H} . \mathrm{H}$ o $\mathrm{l}$ z a p fe 1 , Manuale historiae..., s. $60 \mathrm{n}$.

${ }^{29}$ Tamże, s. $64 \mathrm{n}$.

${ }^{30}$ H. E. W y c z aw ski, Krótka historia Zakonu Braci Mniejszych. W: Klasztory bernardyńskie w Polsce..., s. $593 \mathrm{n}$.

${ }^{31}$ Tamże. 
stawiano na równi z pozbawieniem sprawowanych urzędów i aktów prawnych ${ }^{32}$.

Konstytucje tzw. benedyktyńskie (1336) nazwane tak od zatwierdzającego papieża Benedykta XII (1334-1342) wprowadzały do zakonu św. Franciszka pewne rygory zakonów mniszych, kładąc nacisk na obowiązek chórowego brewiarza, klauzurę klasztorna, dormitoria, regularne studia i inne, natomiast pominęły wyjaśnienia Reguły św. Franciszka odnośnie przestrzegania zasady ubóstwa ${ }^{33}$. Utrwalały więc przekonanie narzucone przez pap. Jana XXII o wyłącznym prawie własności zakonu i konwentu do użytkowanych nieruchomości i rzeczy codziennego użytku, a w tym ksiażek i bibliotek, bez pośrednictwa Stolicy Apostolskiej. Prawodawca wspomniał o książkach w związku ze studiami teologii, które szczególnie promował. Również ze względu na studia nakazywał tworzenie inwentarzy bibliotecznych i ich uzupełnianie za poszczególne lata ${ }^{34}$. Był to pierwszy tego rodzaju nakaz zamieszczony w prawodawstwie Zakonu Braci Mniejszych, powtarzany w niektórych późniejszych konstytucjach zakonu. Problemy związane z rozwojem studiów i bibliotek wyszły tu na pierwszy plan do tego stopnia, że nakazano nowym gwardianom, pod sankcją utraty urzędu, by bezpośrednio po powrocie z kapituły do klasztoru, w pierwszym już miesiącu swoich rządów zapewnili księgozbiorom klasztornym inwentarz, a następnie przedstawili go całej wspólnocie do wgląu ${ }^{35}$. I nie mogło być tak, że jakieś pozycje zostały wymienione $w$ inwentarzu, a nie było ich w rzeczywistości na pułkach bibliotecznych. Autor tych konstytucji wspomniał o wcześniejszym zwyczaju w zakonie, polegającym na tworzeniu spisów czyli rejestrów książek, stąd pierwsze określenie bibliotekarza jako „custos armarii" (kustosz szaf z kodeksami) pochodzi z tych właśnie konstytucji ${ }^{36}$.

W połowie wieku XIV, w okresie rządów generała Wilhelma Farinera (1348-1357) powstały konstytucje tzw. farmerskie (1354) napisane juz w duchu Reguty św. Franciszka, które zezwalały na przechowywanie w konwentach książek dobrodziejów zakonu, zakazywały natomiast przyjmowania złotych przedmiotów i innych kosztowności w depozyt ${ }^{37}$. Dawały władzę przełożonym, by zabierali zakonnikom nadmiar książek z ich cel. Ocena należała do przełożonych, którzy przyjmowali jako kryterium brak właściwego ich wykorzystania w przypadku braci, którzy nie byli ani kaznodziejami, ani studentami, ani lektorami. Podtrzymano nadal karę rekwirowania wszystkich książek w przypadku wspomnianych wyżej wykroczeń przeciw ślubom za-

${ }^{32}$ C. Cen c i, Le Constitucioni Padovane (1310). „AFH”. R. 76:1983, s. 543 nr 51.

${ }^{33}$ H. E. W y c z a w s k i, Krótka historia Zakonu Braci Mniejszych. W: Klasztory bernardyńskie..., s. 591.

${ }^{34}$ M. B ih 1, Ordinationes a Benedicto XII pro Fratribus Minoribus pomulgatae per bullam (28 Nov. 1336). „AFH” R. 30:1937, s. 331 nr 17; Bullarium Franciscanum. T. 6. Ed.

J. H. S b a r a le a, C. E u b e l. Romae 1902, s. 33 nr 51.

${ }^{35}$ Tamże.

${ }^{36}$ Tamże.

${ }^{37}$ Bullarium Franciscanum. T. 6, s. 641. 
konnym, oraz zabraniano przepisywania w skryptoriach klasztornych ksiąg dla celów handlowych, z wyjątkiem trudnych sytuacji finansowych, na co udzielał zgody prowincjał ze swoją kapitułą ${ }^{38}$.

Prawodawstwo zakonu w XIV w., a szczególnie konstytucje potwierdzone przez pap. Benedykta XII zmobilizowały gwardianów większości wielkich konwentów, jak np. św. Franciszka w Asyżu, św. Krzyża we Florencji $^{39}$ - do tworzenia inwentarzy oraz regulaminów bibliotecznych.

Najstarszy znany regulamin biblioteczny, o którym już wyżej wspomniano, został spisany przez generała zakonu, św. Bonawenture i pochodził z ok. $1261 \mathrm{r}^{40}$ Opierał się na ustaleniach konstytucji prenarbońskich, które w całości przejmował i odnosił szczególnie do biblioteki Studium Generalnego w Paryżu. Na pierwszym miejscu zabraniał pisania i przepisywania kodeksów na sprzedaź. Dla dobrego przykładu braci studiujących, regulamin podkreślał, że nawet prowincjałowie nie moga korzystać z książek i ich przetrzymywać u siebie, bez zgody wyższego od siebie przełożonego, czyli generała zakonu. Tym bardziej więc studenci i inni zakonnicy moga korzystać z książek w swoich mieszkaniach jedynie za zgodą prowincjała. $Z$ kolei bracia przenoszący się do innej prowincji, jak wyżej wspomniano, mogli zabierać ze sobą konieczne w pracy kodeksy, z tym jednak, że mieli obowiązek przekazać prowincjałowi prowincji macierzystej sporządzony przez siebie rejestr zabranych ze sobą (wypożyczonych) dzieł, które w przypadku śmierci wypożyczającego miały powrócić do biblioteki konwentu oraz prowincji,

${ }^{38}$ Tamże.

${ }^{39}$ Tamże.

${ }^{40}$ Bonawentura, Giovanni Fidanza, OFM św. (ok. 1217-1274) był teologiem i filozofem. doktorem Kościoła. Studiował w Paryżu na Wydziale Stuk Wyzwolonych (1236-1242) i w 1243 r. wstapił do zakonu. Pod kierunkiem najpierw Aleksandra z Hales, a nastepnie innych profesorów paryskich, studiował teologię. Uzyskawszy bakalaureat w $1248 \mathrm{r}$. wykładał Sentencje P. Lombarda. W latach 1257-1274 był ministrem generalnym (generałem) zakonu. Zasłużył się jako dobry organizator i obrońca życia franciszkańskiego, dlatego nazwano go drugim założycielem Zakonu Braci Mniejszych. Stworzył w 1260 r. Konstytucje tzw. narbońskie (od miejsca obrad kapituły gen. w Narbonne we Francji). Bronił umiarkowanego nurtu w zakonie przed atakami spirytualnych. Napisał m.in. dwie apologie franciszkanizmu: „Kwestie dyskutowane o doskonałości ewangelicznej” (Quaestiones disputatae) i „Apologia ubogich" (Apologia pauperum) przeciw atakujacym zakon: Wilhelmowi z Saint-Amour i Gerardowi z Abbeville. Bronił franciszkanów i dominikanów, wsparty wystapieniem Piotra z Tarentaise, przed zniesieniem, na Soborze Lyońskim, choć inne zakony mendykanckie, których reguły zostały zatwierdzone po Soborze Laterańskim IV, zostały wówczas zniesione (zgodnie z Konstyt. „Różnorodność zakonów” - „Diversitas ordinum” z 1274 r.). B. nie przyjał w 1265 r. nominacji na biskupa Yorku, to jednak w 1273 r. pap. Grzegorz X mianowaì go kardynaiem. Odegrał wazną roię w zorganizowaniu Soboru Lyonskiego 11 doprowadzenia do unii z Grekami (1274). Zmarł w Lyonie 15 VII 1274 r. Kanonizowany w 1482 r., a następnie ogłoszony doktorem Kościola (1588). - E. Z i el i ńs k i, Bonawentura. W: EK. T. 2. Lublin 1986, s. kol. 780; W. F orste r, Bonaventura. W: LfThK. T. 2. Freiburg im B. 1958 , s. 582; H. H ol z a p f e l, Manuale historiae..., s. 30 n., 41, 75; B. B r z u s z e k, Rok św. Bonawentury $w$ świecie $i$ w Polsce. W: W 700-letniq rocznice śmierci. „STV" 13:1975 z. 2, s. 173 n.; C. J. Majch rzak, A Brief History of Bonaventurianism. Pulaski (USA) 1957, s. 53 n.; R. Man ides, Saint Bonaventura. Les Frčres Mineurs et l' unité de l'Eglise au Concile de Lyon. „La France Franciscaine” 18:1935, s. 375 n. 
z jałmużny której zostały nabyte. Mieli tej sprawy dopilnować prowincjałowie macierzystej prowincji zmarłego ${ }^{41}$.

Ponadto Regulamin paryski zabraniał studentom i profesorom przetrzymywać ksiażki spoza zakonu, którymi prowincjałowie nie mogli prawnie dysponować, czyli przydzielać je podwładnym lub bibliotekom klasztornym. Kodeksy Pisma św. mogli mieć do użytku jedynie bracia przeznaczeni do studiów lub do pracy w kaznodziejstwie. Wszakże i oni byli zobowiązani przestrzegać zasady ubóstwa i nie nabywać egzemplarzy o cenie rynkowej wyższej niż 20 monet paryskich (,20 librarum parisiensium vel turonensium" $)^{42}$. Bracia studiujący i korzystający z biblioteki konwentu paryskiego mieli co pewien czas, w okresie wizytacji prowincjalskiej deklarować wizytatorowi rezygnacje $\mathrm{z}$ książek $\mathrm{i}$ innych rzeczy danych sobie do codziennego użytku, by tym podkreślić, że nie są ich właścicielami. Przy tej okazji wizytatorzy powinni byli zabierać braciom książki przez nich nie wykorzystane i nie konieczne w ich pracy, a następnie rozdzielać je tym, którzy ich nie posiadali, a zwłaszcza kaznodziejom, by mogli je wykorzystać dla dobra duchowego wiernych ${ }^{43}$.

Kolejne regulaminy (ordinationes) pochodziły już $\mathrm{z}$ wieku XIV i uwzględniały ważny nakaz konstytucji papieża Benedykta XII (1336) o konieczności tworzenia inwentarzy bibliotecznych pod sankcją utraty urzędu przez gwardiana konwentu. Stąd szczególnie w drugiej połowie wieku zaczęto tworzyć względnie udoskonalać inwentarze kodeksów bibliotecznych. Do bardziej znanych i opracowanych źródłowo należały inwentarze względnie regulaminy wielkich bibliotek, jak biblioteka Konwentu św. Krzyża we Florencji autorstwa brata Bernarda de Guasconibus z ok. $1356-1367 \mathrm{r}^{44}$ oraz Biblioteka Sacro Convento w Asyżu z roku $1381^{45}$, opracowany i wydany przez Leto Alessandri'ego.

Regulamin Biblioteki Konwentu św. Krzyża we Florencji nie wspominał jeszcze o potrzebie pisania inwentarzy, ale stanowił przykład realizacji w praktyce uchwał konstytucji generalnych z 1336 r., wówczas aktualnie obowiązujących, oraz prawodawstwa wcześniejszego. Stworzył go prowincjał Bernard de Guasconibus, który osobiście zaangażował się w sprawy związane $\mathrm{z}$ normalnym funkcjonowaniem bibliotek klasztornych w swojej prowincji, a szczególnie florenckiej, dlatego bibliotekę klasztoru św. Krzyża we Florencji uczynił wzorcową dla innych bibliotek klasztornych kustodii

${ }^{41}$ S. B on ave n t u ra, Opera omnia. T. 8. Ed. Collegii s. Bonaventurae. Quaracchi (p. Florentiam) 1898, s. $457 \mathrm{nr} 6$.

${ }^{42}$ Ówczesna jednostka monetarna we Francji, odpowiednik 1. marki, będącej w użyciu w Paryżu również w w. XIII i XIV. - Tamże.

${ }^{43}$ Tamże.

${ }^{44}$ J. M. B ih 1, Ordinationes fr. Bernardi de Guasconibus pro Bibliotheca Conventus S. Crucis in Florentia, 1356-1367. "AFH”. R. 30:1937, s. 149.

${ }^{45} \mathrm{~L}$. A less andri, Inventario del antica Biblioteca del Sacro Convento di San Francesco in Assisi compilato nel 1381. Assisi 1906 (Rec.:) Th. D o me n i ch elli. „AFH”. R. 21:1908 fasc. 1, s. 127. 
i nadał jej opracowany przez siebie Regulamin ${ }^{46}$. W świetle szczegółowych 25. przepisów odnoszących się do zarządzania i korzystania z tego księgozbioru uczynił z niego prawie niezależna od konwentu instytucję. Wyjął spod władzy gwardiana klasztoru i podporządkował sobie jako prowincjałowi między innymi takie sprawy jak nominacja względnie usuwanie bibliotekarza z jego funkcji, tłumacząc to pewną ciaggłością prac w bibliotece (Reg. $\mathrm{nr} 16$ ). Ponadto bibliotekarz miał należeć zawsze do komisji przeglądającej wstępnie kodeksy po zmarłych braciach, by wybrać te z nich, które należały względnie nadawały się do biblioteki konwenckiej (Reg. nr 11). Jego obowiązkiem było już na wstępie stworzenie rejestru książek po zmarłym, by je można było odpowiednio zakwalifikować i przenieść na właściwe miejsce, a najbardziej do biblioteki konwentu (Reg. nr 11). Przepisem, który wyraźnie podnosił range bibliotekarza w klasztorze był punkt $\mathrm{nr} 7$, zabraniający przełożonemu konwentu oraz innym zakonnikom wypożyczać lub w inny sposób wydawać książki klasztorne bez zgody i wiedzy bibliotekarza. Chodziło bowiem o to, by bibliotekarz spisał te kodeksy w osobnym rejestrze i dokładnie zaznaczył czas oraz warunki zwrotu do biblioteki klasztornej (Reg. nr 4--5). Prowincjał, twórca Regulaminu uzależnił od swojego bezpośredniego nadzoru, a także od zdania dyskretów klasztoru decyzję w tak ważnej sprawie, związanej z rozwojem biblioteki, jak sprzedaż oraz zamiana książek mało użytecznych na bardziej potrzebne i zapewne nowsze (Reg. $\mathrm{nr} 2-3,15)^{47}$. Zawsze w sprawach wątpliwych, czy dane kodeksy zostały ofiarowane przez dobrodziejów do biblioteki konwenckiej, czy biblioteki studium filozoficzno-teologicznego, Bernard w swoim regulaminie przychylał się do decyzji, by włączać je do biblioteki klasztornej (Reg. $\mathrm{nr}$ 14). Swoje zainteresowania rozwojem biblioteki Bernard de Guasconibus wyraził w punkcie nr 9 Regulaminu, gdzie wymagat, „by bez zwłoki”, na żądanie bibliotekarza poświadczone „rejestracja” (rachunkiem), przełożeni wyasygnowali odpowiednie środki finansowe na kupno nowych książek ${ }^{48}$.

Niektóre przepisy Regulaminu florenckiego wskazują na to, że biblioteka tamtejszego konwentu była nie tylko wzorcowa, ale traktowano ją w konwentach kustodii za bibliotekę centralna, z której zakonnicy kustodii mieli prawo korzystać i wypożyczać kodeksy potrzebne w pracy, m.in. kaznodziejskiej i dydaktycznej (w studiach zakonnych). Wypożyczający byli jednak zobowiązani raz w roku przywieźć wypożyczone książki osobiście do konwentu kustodialnego, by je przedstawić kustoszowi kustodii, gwardianowi i bibliotekarzowi biblioteki centralnej kustodii. I to był warunek prolongaty dalszego $z$ nich korzystania. W przeciwnym razie, gdyby ktoś z braci nie spełnił tego warunku, miał być karnie pozbawiony wypożyczonych książek. Miał je zwrócić do biblioteki, bez szansy ich ponownego wypożyczenia w danym roku (Reg. nr 13).

\footnotetext{
${ }^{46}$ Tamże.

${ }^{47}$ Tamże.

${ }^{48}$ Tamże.
} 
Celem zabezpieczenia zbiorów autor Regulaminu szczególnie uwrażliwiony na braci użytkowników książek, wyjeżdżających z konwentu na dłużej niż trzy dni, nakazywał im zwracanie wypożyczonych kodeksów przed wyjazdem, a gdy tego nie uczynili, to po powrocie pozbawiano ich czasowo prawa korzystania z biblioteki. I wówczas nawet miejscowy gwardian nie mógł im tej kary zamienić na inną (Reg. nr 6). Ponadto, aby przekonać się, że bracia korzystający w swoich celach z książek wypożyczonych z biblioteki konwenckiej, rzeczywiście przechowywali je u siebie, mieli co $15 \mathrm{dni}$, a później raz na cztery miesiące zbierać się na głos dzwonka klasztornego i okazać bibliotekarzowi wypożyczone przez siebie kodeksy, zgodnie z rejestrem, sporządzonym wcześniej przez siebie. I w tym przypadku dla nieposłusznych groziła kara pozbawienia kodeksów bibliotecznych na miesiąc oraz jednorazowa abstynencja od posiłku mięsnego podczas obiadu (Reg. nr 8$)^{49}$.

Zasady funkcjonowania biblioteki autorstwa Bernarda de Guasconibus z 1356 r., w zestawieniu z omówionym wyżej Regulaminem paryskim św. Bonawentury (1261) przewyższały je przede wszystkim bogatszą problematyką biblioteczną. Ukazywały bowiem działanie instytucji bibliotecznej w praktyce i jej charakter społeczny w skali całej kustodii zakonnej. Regulamin paryski niemal dosłownie przejmował tylko to, co o książkach i księgozbiorach zakonnych zawierały najwcześniejsze konstytucje zakonu, tzw. prenarbońskie. Oba regulaminy, z XIII i XIV wieku nie przewidywały jeszcze inwentaryzacji zbiorów, choć florencki powstał już po wydaniu konstytucji pap. Benedykta XII, które wyraźnie nakazywały tworzenie inwentarzy. Kładł jednak nacisk na tworzenie rejestrów np. książek wypożyczanych lub pozostałych po zmarlych zakonnikach ${ }^{50}$.

Niechęć zakonu do wspomnianych konstytucji benedyktyńskich (1336) odbiła się również na wprowadzaniu w życie ich ustaleń o bibliotekach, skądinąd bardzo ważnych, bo stawiających organizację tychże na wyższym niż dotychczas poziomie. Wzorcowa biblioteka we Florencji, w dwadzieścia lat po ogłoszeniu konstytucji nie wspomniała w swoim Regulaminie o potrzebie tworzenia inwentarzy. Było zapewne podobnie i w innych bibliotekach prowincjalnych w zakonie. Dopiero w 1381 r. brat Jan Joli w Sacro Convento w Asyżu stworzył inwentarz dla kilkuset kodeksów pierwszej biblioteki w zakonie. Sądząc po ich weryfikacji na początku obecnego wieku, było ich wówczas ponad 300 woluminów ${ }^{51}$. Inwentaryzacja biblioteki w najstarszym konwencie zakonu stała się zapewne wzorem i przykładem dla innych bibliotek w klasztorach franciszkanów konwentualnych, a następnie w grupie obserwanckiej w wieku XV.

\footnotetext{
${ }^{49}$ M. B i h 1, Ordinationes fr. Bernardi..., s. 149 nr 6; s. 150 nr 8.

${ }^{50}$ Tamże, s. $149 \mathrm{nr} 5,7,12$.

${ }^{51}$ L. A les s and ri, Inventario..., s. 127 n.
} 